\title{
Analysis the impact of Information technology on Efficient tax Management
}

\author{
Pshdar Abdalla Hamza ${ }^{1}$, Khowanas Saeed Qader², Bayar Gardi ${ }^{3}$, Hawkar Anwar \\ Hamad $^{4}$, Dr. Govand Anwar ${ }^{5}$
}

\author{
${ }^{1}$ Department of Business Administration, Kurdistan Technical Institute, Sulaymaniyah, Iraq. \\ ${ }^{2,4}$ Department of Accounting and Finance, College of Administrations and Economics, Lebanese French university, \\ Kurdistan region, Iraq.
}

${ }^{3}$ Department of Accounting, College of Administration and Financial Sciences, Knowledge University, Kirkuk Road, 44001 Erbil, Kurdistan Region, Iraq.

${ }^{5}$ Business Administration, Global University of Erbil, Kurdistan region, Iraq.

Received: 25 Aug 2021; Received in revised form: 11 Sep 2021; Accepted: 15 Sep 2021; Available online: 28 Sep 2021

\begin{abstract}
The purpose of this study was to investigate the influence of information technology on tax administration in the Kurdistan. The impact of information technology on tax productivity as well as the link between information technology on tax implementation and tax planning were especially studied in this study. In this study, a descriptive research approach was adopted, with a questionnaire being used to collect data, which was then analyzed using multiple regression and Pearson product moment correlation. The findings of the study revealed that information technology (online tax filing, online tax registration and online tax remittance) has a positive impact on efficient tax management.
\end{abstract}

Keywords-E-filling, IT, Tax Management, Accounting Management, Taxation.

\section{INTRODUCTION}

Tax authorities, as an agency of government, are increasingly turning to e-government led solutions such as electronic tax filing (e-filing) on the grounds that it improves the delivery of public services and fiscal efficiency (Hamza et al. 2021). Sabir et al. (2021) defined e-taxation as "a process in which tax documents or taxes returns are submitted through the internet, usually without the need to submit any paper returns." E-taxation includes the use of internet technology, the Worldwide Web, and software for a wide range of tax administration and compliance purposes, according to the (Aziz et al. 2021). The term "electronic tax filing" was developed in the United States, where the Internal Revenue Service (IRS) began enabling tax return e-filing for tax refunds only in 2003, establishing the precedent (Sorguli et al. 2021). Individual taxpayers are now filing online in greater numbers than ever before, with about one out of every five individuals now doing so. In reality, this was made possible by various upgrades and features that have been introduced to the software throughout time, as shown below (Ahmed et al. 2021). Other industrialized countries, such as Australia, Canada, and Italy, have now adopted electronic filing as a standard practice (Ismael et al. 2021). The United Kingdom, Chile, Ireland, Germany, France, the Netherlands, Finland, Sweden, Switzerland, Norway, Singapore, Brazil, Mexico, India, China, Thailand, Malaysia, and Turkey are among the countries participating in the competition (Ali et al. 2021). E-filing of tax returns has also been popular in Kurdistan as well as other emerging nations like as Uganda, Rwanda, and Kenya, among others (Gardi, 2021).

Several tax authorities around the world, according to Qader et al. (2021), are implementing electronic tax administration systems to interact with the taxpaying public in tax collection, administration, and compliance settings in order to improve the effectiveness and efficiency of tax 
administration and collection (Hamza et al. 2021). Previous studies on the suitability of an information technologyenabled tax system have found that there is a positive relationship between the use of automation systems and the cost of tax administration, as well as a link between automation and the effectiveness of revenue collection (Fatah et al. 2021), as demonstrated by a case study of the customs division (Hamad et al. 2021). Using the comparative case studies of Brazil and Japan, (Ali \& Hamad, 2021) focused on the economic development and taxation systems of the two countries' respective economies. Japan's example proved that a nation does not need to wait until it reaches a high degree of development before making significant changes to its tax structure, whereas in Brazil, low-income taxpayers carry the lion's share of the cost of taxation (Hamad, 2018). According to Ali \& Anwar, (2021), an automated system improves administration by providing multiple scenarios that allow senior management in a multicampus university system to generate multiple income scenarios, make well-informed decisions about the operation of their institution, and calculate and allocate resources to academic departments on a time-sensitive basis (Anwar \& Shukur,2015). As evidenced by Anwar \& Abdullah, (2021), a macro model outperforms the representative tax system when it comes to variations in funds allocated to counties, and Abdullah \& Anwar, (2021) revealed that a system that combines spatial and attribute data management capabilities, such as geographic information systems, is the most effective method of planning for revenue collection. While Anwar \& Abd Zebari, (2015) found that an online tax system does have an impact on tax compliance levels among small taxpayers, Anwar \& Surarchith, (2015) found that there is a relationship between information systems and revenue collection efficiency and effectiveness, and that there is a particularly significant link between internal controls and revenue collection (Hameed \& Anwar, 2018). Abdullah et al. (2017) concluded that the use of modern technology eliminates any opportunity for tax evaders to hide because the system captures all potential taxpayers. However, the use of information and communications technology (ICT) can be catastrophic if it is used carelessly by both tax payers and tax administrators because scammers and hackers of internet facilities can take advantage of the ignorance of the public or the lax security of the system (Anwar \& Balcioglu, 2016). Given the foregoing, no studies have yet been conducted to investigate the impact of information technology, specifically online tax filing, online tax registration (Anwar, 2016), and online tax remittance, on the level of tax administration in terms of tax productivity, planning, and implementation. This demonstrates that there is a gap in the existing literature (Anwar, 2017). It is true that Anwar \& Ghafoor, (2017) investigated how the online tax system affected the filing and remittance of taxes, but their findings were based on tax compliance rather than the use of technology to file taxes online. As a result, the purpose of this study is to investigate the influence of information technology on tax administration, with a particular focus on Kurdistan (Anwar \& Qadir, 2017).

\section{LITERATURE REVIEW}

In information technology (IT), tools, equipment, and resources are used to interact with one another, as well as with other people, and to produce, manage, and share information (Anwar \& Climis, 2017). The term "information technology" refers to a group of technologies that include hardware such as computers and modems, as well as software such as computer programs and mobile phone applications, as well as networks such as wireless communications and the Internet (Anwar \& Louis, 2017). They are primarily concerned with the collection, processing, storing, and transmitting relevant information to support the management operations of any organization, including government agencies, and are comprised of hardware such as computers and modems, as well as software such as mobile phone applications (Anwar, 2015). Individuals who are associated with institutions or government systems can benefit from a system that provides accurate history information, current status information, and predicted information, all of which is accurately stated (Anwar \& Shukur, 2015). According to Anwar \& Abd Zebari, (2015), information technology is advantageous in the area of decision making because it has the ability to monitor and diagnose system disturbances on its own, determine a course of action, and take action in order to bring the system back into balance. The following components are included in the construction of future planning information technology according to Anwar \& Surarchith, (2015): people, data processing, data transmission, information system and retrieval, and system planning (Anwar, 2017). The taxation system, according to Anwar \& Louis, (2017), is a powerful and possibly financially stabilizing tool that governments of nations may utilize to construct development goals while also maintaining fiscal stability in their countries. The major objective of tax administration across the world is to generate revenue to finance government expenditure on social welfare, which includes defense, law and order, health-care services, and educational opportunities for residents (Anwar, 2015). In addition to funding capital projects, which are also known as consumer spending, tax revenue may also be used to fund consumer spending, which includes the development of social and economic 
infrastructure that will improve the quality of people's lives (Hameed \& Anwar, 2018). Beyond its primary function, taxation can also be used as a critical instrument in any nation's economy to promote investment through the use of tax breaks, incentives, or other attractive tax exemptions that appeal to both domestic and foreign investors in areas such as manufacturing of consumer products (Abdullah et al. 2017), export processing, and petroleum and natural gas production. It is also standard practice to use taxation as a tool to discourage specific types of antisocial conduct in the community. Use of alcohol, smoking, and pool betting are all instances of anti-social conduct that can be curtailed by the imposition of higher taxes on the manufacturing of these goods in the first place (Anwar \& Balcioglu, 2016). According to Anwar, (2016), a sound tax system must be based on the following concepts in order to be effective: In order to guarantee that taxpayers comply with the tax laws and that tax administrators operate efficiently, the effectiveness of a tax system is determined by its capacity to promote the ethical principles of professionalism, openness, accountability for actions, probity, and efficiency in the collecting of taxes. Simplicity (Anwar, 2017): A simple, flexible, and adaptive tax system, as well as the tax legislation, should guarantee that taxpayers comply with the law while tax administrators operate efficiently; neutrality, which suggests that a good tax system should be free of any sort of prejudice; economy, which implies that a good tax system should make the economic situation better rather than worse (Anwar \& Ghafoor, 2017); and fairness, which implies that a good tax system should be devoid of any type of bias. also means the absence of any type of bias in a good tax system, which suggests that a good tax system should be devoid of any form of favoritism (Anwar \& Qadir, 2017). It is not permitted to have a detrimental influence on the economic contribution of the taxpaying population (Anwar, 2015). It is necessary, in particular, that both the compliance costs to tax payers and the administrative expenses to government have no negative influence on the total amount of taxes collected at the national level (Hamza et al. 2021). In order to be equitable, a sustainable tax system cannot be arbitrary, nor should the amount payable be affected by prejudice or personal sentiments. This concept specifies that the time of payment, the manner of payment, and the amount to be paid must be clear to the tax payer as well as the taxing authorities (Sabir et al. 2021); convenience, on the other hand, requires that a good tax system be capable of generating a subsistence for the tax payer (Aziz et al. 2021). To be successful in implementing electronic filing and payment systems, Sorguli et al. (2021) states that the following conditions must be met: reliable and accessible internet service, cooperative financial institutions, a technologically astute public, and adequate funding to set up the necessary infrastructure in tax offices (Ahmed et al. 2021). e-filing and e-payment systems must be incorporated into a complete information technology design, development, and implementation plan, as pointed out by Ismael et al. (2021) in order to be effective. As Ali et al. (2021) pointed out, in order for e-filing to be effective, the following factors are required: skilled personnel, a reliable IT infrastructure, and a good business climate (Gardi, 2021). The documentation of ideas and actions, as well as desired outcomes and time frames for each component, is the first step in the development of a strategic business plan for electronic tax systems. This is done while taking into account the strengths and weaknesses of the tax administration, as well as environmental opportunities and threats (Qader et al. 2021). It is also recommended that the plan contain a description of the implementation strategy, which should include the approach for putting it into effect (Hamad et al. 2021). Many countries have chosen a staged approach to the introduction of optional electronic filing and payment for particular segments of the taxpayer base, such as individuals or companies, as part of a phased plan to allow for live testing of the system in the early stages (Fatah et al. 2021). Taxpayers with specific characteristics, such as companies, are obliged to file returns following the conclusion of testing (Ali \& Hamad, 2021). Additionally, a stable electricity supply, periodic seminars for tax payers and tax authorities on the system's usage, a secure, userfriendly, and readily assessable website, as well as a legislative framework, are required for a successful electronic taxation system to be implemented (Hamad, 2018). For example, Ali \& Anwar, (2021) identified the following as benefits of utilizing information technology to manage the operations and delivery of services by public sector institutions: increased administrative efficiency, effectiveness, and productivity, improved service delivery quality (Anwar \& Shukur,2015), and a reduction in the administration, operational, and transactional costs of public institutions (Anwar \& Abdullah, 2021). They also spoke on the need of providing knowledge at a reduced cost. There are no words to adequately express how important IT is in the field of taxation (Abdullah \& Anwar, 2021), with some examples being: a reduction in the overhead costs of managing the government agencies responsible for tax administration, instant computation of tax liability through the use of online tax calculators, reduced cost of registering tax payers and instant generation of tax identification number, a reduction in staff-taxpayers collusion as it relates to tax liability (Anwar \& Shukur, 2015), a reduction in the number of tax returns filed, a reduction in the number of tax returns filed by individuals (Anwar \& Abd Zebari, 2015). It is expected that building an information technology system will result in greater productivity, improved profit 
performance, as well as a higher degree of accuracy in information, according to the research of (Anwar \& Surarchith, 2015). Most firms that embrace information technology see increased productivity, but there may be some productivity loss during the "learning curve" period (Anwar, 2017). Using information technology in tax administration can result in a high level of ill will toward tax payment, garbage-in garbage-out, which is the imputation of incorrect figures that will result in incorrect calculation of tax liability by online tax calculator (Hameed \& Anwar, 2018), poor internet access, inadequate electricity to power host servers, high costs of maintaining ICT facilities, a lack of technical know-how by tax administration agencies, and a high level of indifference toward tax payment (Abdullah et al. 2017).

\section{RESEARCH METHODOLOGY}

The research was conducted out in the Kurdistan, which included the states of Erbil, Duhok, and Sulaimaniah. According to the descriptive survey design, the study population included all members of staff in government agencies responsible for tax administration in Kurdistan, while the sample included members of staff excluding unprofessional cadre, and the sample was purposively selected from the population.

The questionnaire was employed as the study instrument, and the face and content validity tests, as well as the testretest procedure, were used to assess its validity and reliability. Following that, it was administered to a total of eighty-nine members of staff from the aforementioned organizations. Several types of inferential statistics, including regression and Pearson and correlation, were employed in the analysis of the data gathered.

In order to examine the influence of information technology on efficient tax management, the study used

Online tax filing, Online tax registration, as independent variables and efficient tax management as dependent variable. For this reason, the study developed the followings research hypotheses:

H1: Online tax filing has a positive and significant influence on efficient tax management.

$\mathrm{H} 2$ : Online tax registration has a positive and significant and efficient tax management.

H3: Online tax remittance has a positive and significant influence on and efficient tax management.

\section{FINDINGS AND ANALYSIS}

Table 1: Reliability Analysis

\begin{tabular}{|l|l|l|}
\hline Variables & $\mathrm{N}$ & Cronbach's Alpha \\
\hline Online tax registration & 7 & .829 \\
\hline Online tax filing & 7 & .770 \\
\hline Online tax remittance & 7 & .741 \\
\hline Efficient tax management & 10 & .773 \\
\hline
\end{tabular}

The researcher implemented reliability analysis to (as seen in table-1) the values of Cronbach's Alpha for online tax registrationas independent factor, found to be $.829>.6$ this indicates that the items used to measure online tax registrationfactor were reliable for the current study, the values of Cronbach's Alpha for online tax filing as independent factor, found to be $.770>.6$ this indicates that the items used to measure online tax filing factor were reliable for the current study, the values of Cronbach's Alpha for online tax remittance as independent factor, found to be $.741>.6$ this indicates that the items used to measure online tax remittance factor were reliable for the current study.

Table.2:Correlation Analysis

\begin{tabular}{|l|l|l|l|l|l|}
\hline & Pearson & $\begin{array}{l}\text { Online tax } \\
\text { filing }\end{array}$ & $\begin{array}{l}\text { Online tax } \\
\text { registration }\end{array}$ & $\begin{array}{l}\text { Online tax } \\
\text { remittance }\end{array}$ & Efficient tax management \\
\hline & Correlation & 1 & & & \\
\cline { 2 - 6 } Sig. (2-tailed) & & & & \\
\cline { 2 - 6 } & $\mathrm{N}$ & 89 & & & \\
\hline
\end{tabular}




\begin{tabular}{|c|c|c|c|c|c|}
\hline \multirow{4}{*}{ Online tax filing } & Pearson & $.399 * *$ & 1 & & \\
\hline & Correlation & & & & \\
\hline & Sig. (2-tailed) & .000 & & & \\
\hline & $\mathrm{N}$ & 89 & 89 & & \\
\hline \multirow{4}{*}{$\begin{array}{ll}\text { Online } & \text { tax } \\
\text { registration } & \end{array}$} & Pearson & $.576^{* *}$ & $.470 * *$ & 1 & \\
\hline & Correlation & & & & \\
\hline & Sig. (2-tailed) & .000 & .000 & & \\
\hline & $\mathrm{N}$ & 89 & 89 & 89 & \\
\hline \multirow{4}{*}{$\begin{array}{ll}\text { Online } & \text { tax } \\
\text { remittance } & \end{array}$} & Pearson & $.347 * *$ & $.389 * *$ & $.365 * *$ & 1 \\
\hline & Correlation & & & & \\
\hline & Sig. (2-tailed) & .000 & .000 & .000 & \\
\hline & $\mathrm{N}$ & 89 & 89 & 89 & 89 \\
\hline \multirow{3}{*}{$\begin{array}{ll}\text { Efficient } & \text { tax } \\
\text { management } & \end{array}$} & Pearson & $.632 * *$ & $.696 * *$ & $.615 * *$ & $.611^{* * *}$ \\
\hline & Correlation & & & & \\
\hline & Sig. (2-tailed) & .000 & .000 & .000 & .000 \\
\hline
\end{tabular}

The researcher attempted to find the correlation between nine independent variables and a dependent variable, therefore the correlation analysis was implemented (as seen in table-2). It was found that the value of Pearson correlation for online tax filing $=.632 * *>.0 .01$ therefore there is a positive and significant correlation between online tax filing and efficient tax management, in terms of the strength it was found to be a moderate correlation, the value of Pearson correlation for personal influence $=.696^{* *}>$
.0 .01 therefore there is a positive and significant correlation between online tax registration and efficient tax management, in terms of the strength it was found to be a strong correlation, the value of Pearson correlation for online tax remittance $=.615^{* *}>.0 .01$ therefore there is a positive and significant correlation between online tax remittance and efficient tax management, in terms of the strength it was found to be a weak correlation.

\section{Table.3: Model Summary}

\begin{tabular}{|l|l|l|l|l|}
\hline \multicolumn{5}{|c|}{ Model Summary } \\
\hline Model & R & R Square & Adjusted R Square & Std. Error of the Estimate \\
\hline 1 & $.736 a$ & .542 & .538 & .33447 \\
\hline
\end{tabular}

a. Predictors: (Constant), online tax filing, online tax registration and online tax remittance

It was found that the value of $\mathrm{R}$ square $=.542$ (as seen in table-3) this indicates that $54 \%$ of the variables have been explained.

Table 4: ANOVA

\begin{tabular}{|c|c|c|c|c|c|c|}
\hline \multicolumn{7}{|c|}{ ANOVA } \\
\hline Model & & Sum of Squares & df & Mean Square & $\mathrm{F}$ & Sig. \\
\hline \multirow[t]{3}{*}{1} & Regression & 129.814 & 9 & 14.424 & 128.933 & $.000 \mathrm{~b}$ \\
\hline & Residual & 109.745 & 981 & .112 & & \\
\hline & Total & 239.559 & 990 & & & \\
\hline \multicolumn{7}{|c|}{ a. Dependent Variable: efficient tax management } \\
\hline
\end{tabular}

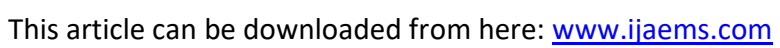


It was found the value $\mathrm{F}=128.933$ and since the value is greater than .001 , this indicates that that there is a positive association between variables used to test research hypotheses.

Table.5: Coefficients

\begin{tabular}{|c|c|c|c|c|c|c|}
\hline \multirow{2}{*}{$\begin{array}{l}\text { Model } \\
1\end{array}$} & & \multicolumn{2}{|c|}{$\begin{array}{l}\text { Unstandardized } \\
\text { Coefficients }\end{array}$} & \multirow{2}{*}{$\begin{array}{l}\text { Standardized } \\
\text { Coefficients } \\
\text { Beta }\end{array}$} & \multirow[t]{2}{*}{$\mathrm{t}$} & \multirow[t]{2}{*}{ Sig. } \\
\hline & & $\mathrm{B}$ & Std. Error & & & \\
\hline & (Constant) & .687 & .104 & & 6.617 & .000 \\
\hline & Online tax filing & .448 & .023 & .521 & 19.213 & .000 \\
\hline & $\begin{array}{ll}\text { Online } & \operatorname{tax} \\
\text { registration } & \end{array}$ & .584 & .023 & .630 & 25.509 & .000 \\
\hline & $\begin{array}{ll}\text { Online } \\
\text { remittance }\end{array} \quad$ tax & .671 & .024 & .662 & 27.796 & .000 \\
\hline
\end{tabular}

a. Dependent variable: Efficient tax management

The researcher utilized multiple regression analysis to find the most effective and suitable factors increasing level of efficient tax management in private companies in Kurdistan. It was found that the value of B for online tax filing $=.448>.001$ and $\mathrm{P}$-value $=.000$, this indicated that there is positive relationship between online tax filing and efficient tax management, accordingly the first research hypothesis was supported which stated that " Online tax filing has a positive and significant influence on efficient tax management ", moreover the value of B for personal influence $=.584>.001$ and $\mathrm{P}$-value $=.000$, this indicated that there is positive relationship between online tax registration and efficient tax management, accordingly the second research hypothesis was supported which stated that " online tax registration has a positive and significant and efficient tax management ", and the value of B for Online tax remittance $=.674>.001$ and $\mathrm{P}$-value $=.000$, this indicated that there is positive relationship between Online tax remittance and efficient tax management, accordingly the third research hypothesis was supported which stated that " Online tax remittance has a positive and significant influence on and efficient tax management.

\section{CONCLUSION}

Tax authorities, as an agency of government, are increasingly turning to e-government led solutions such as electronic tax filing on the grounds that it improves the delivery of public services and fiscal efficiency. Several tax authorities around the world, they are implementing electronic tax administration systems to interact with the taxpaying public in tax collection, administration, and compliance settings in order to improve the effectiveness and efficiency of tax administration and collection. It is revealed that a system that combines spatial and attribute data management capabilities, such as geographic information systems, is the most effective method of planning for revenue collection. However, the use of information and communications technology (ICT) can be catastrophic if it is used carelessly by both tax payers and tax administrators because scammers and hackers of internet facilities can take advantage of the ignorance of the public or the lax security of the system. The taxation system is a powerful and possibly financially stabilizing tool that governments of nations may utilize to construct development goals while also maintaining fiscal stability in their countries. The major objective of tax administration across the world is to generate revenue to finance government expenditure on social welfare, which includes defense, law and order, health-care services, and educational opportunities for residents. In addition to funding capital projects, which are also known as consumer spending, tax revenue may also be used to fund consumer spending, which includes the development of social and economic infrastructure that will improve the quality of people's lives. Beyond its primary function, taxation can also be used as a critical instrument in any nation's economy to promote investment through the use of tax breaks, incentives, or other attractive tax exemptions that appeal to both domestic and foreign investors in areas such as manufacturing of consumer products, export processing, and petroleum and natural gas production. It is also standard practice to use taxation as a tool to discourage specific types of antisocial conduct in the community. Use of alcohol, smoking, and pool betting are all instances of anti-social conduct that can be curtailed by the imposition of higher 
taxes on the manufacturing of these goods in the first place. The documentation of ideas and actions, as well as desired outcomes and time frames for each component, is the first step in the development of a strategic business plan for electronic tax systems. This is done while taking into account the strengths and weaknesses of the tax administration, as well as environmental opportunities and threats. It is also recommended that the plan contain a description of the implementation strategy, which should include the approach for putting it into effect. Many countries have chosen a staged approach to the introduction of optional electronic filing and payment for particular segments of the taxpayer base, such as individuals or companies, as part of a phased plan to allow for live testing of the system in the early stages. Taxpayers with specific characteristics, such as companies, are obliged to file returns following the conclusion of testing.

The researcher utilized multiple regression analysis to find the most effective and suitable factors increasing level of efficient tax management in private companies in Kurdistan. It was found that the value of $\mathrm{B}$ for online tax filing $=.448>.001$ and $\mathrm{P}$-value $=.000$, this indicated that there is positive relationship between online tax filing and efficient tax management, accordingly the first research hypothesis was supported which stated that " Online tax filing has a positive and significant influence on efficient tax management ", moreover the value of B for personal influence $=.584>.001$ and $\mathrm{P}$-value $=.000$, this indicated that there is positive relationship between online tax registration and efficient tax management, accordingly the second research hypothesis was supported which stated that " online tax registration has a positive and significant and efficient tax management ", and the value of B for Online tax remittance $=.674>.001$ and $\mathrm{P}$-value $=.000$, this indicated that there is positive relationship between Online tax remittance and efficient tax management, accordingly the third research hypothesis was supported which stated that " Online tax remittance has a positive and significant influence on and efficient tax management.

\section{REFERENCES}

[1] Fatah, N. A., Hamad, H. A., \& Qader, K. S. (2021). The Role of Internal Audit on Financial Performance Under IIA Standards: A Survey Study of Selected Iraqi Banks. QALAAI ZANIST SCIENTIFIC JOURNAL, 6(2), 1028-1048.

[2] Ali, D. J., \& Hamad, H. A. (2021). The role of the cash flow statement to provide accounting information for the financial decision-making process:(Case study International Islamic Bank of Kurdistan in the year 2018). QALAAI ZANIST SCIENTIFIC JOURNAL, 6(2), 870-887.

[3] HAMAD, H. (2018). Customer Satisfaction In Banking Sector: The Case In North Iraq, City Of Erbil.
[4] Olatunji, O. C., \& Ayodele, K. B. (2017). Impact Of Information Technology On Tax Administration In Southwest Nigeria. Archives of Business Research, 5(9), 139-150.

[5] Ali, B. J., \& Anwar, G. (2021). The Effect of Marketing Culture Aspects of Healthcare Care on Marketing Creativity. Ali, BJ, \& Anwar, G.(2021). The Effect of Marketing Culture Aspects of Healthcare Care on Marketing Creativity. International Journal of English Literature and Social Sciences, 6(2), 171-182.

[6] Khuntia, J., Saldanha, T. J., Mithas, S., \& Sambamurthy, V. (2018). Information technology and sustainability: Evidence from an emerging economy. Production and Operations Management, 27(4), 756-773.

[7] Ali, B. J., \& Anwar, G. (2021). An Empirical Study of Employees' Motivation and its Influence Job Satisfaction. Ali, BJ, \& Anwar, G.(2021). An Empirical Study of Employees' Motivation and its Influence Job Satisfaction. International Journal of Engineering, Business and Management, 5(2), 21-30.

[8] Oláh, J., Karmazin, G., Pető, K., \& Popp, J. (2018). Information technology developments of logistics service providers in Hungary. International Journal of Logistics Research and Applications, 21(3), 332-344.

[9] Anwar, G., \& Shukur, I. (2015). The Impact of Training and Development on Job Satisfaction: A Case Study of Private Banks in Erbil. International Journal of Social Sciences \& Educational Studies, 2(1), 65.

[10] Ali, B. J., \& Anwar, G. (2021). Factors Influencing the Citizens' Acceptance of Electronic Government. International journal of Engineering, Business and Management (IJEBM), 5.

[11] Nayyar, A., \& Singh, I. (2018). A comprehensive analysis of Goods and Services Tax (GST) in India. Indian Journal of Finance, 12(2), 57-71.

[12] Ali, B. J., \& Anwar, G. (2021). The balanced scorecard's evolution as a strategic mechanism at banking sectors. Ali, BJ, \& Anwar, G.(2021). The Balanced Scorecard'S Evolution as a Strategic Mechanism at Banking Sectors. International Journal of English Literature and Social Sciences, 6(1), 471-478.

[13] Anwar, G., \& Abdullah, N. N. (2021). The impact of Human resource management practice on Organizational performance. International journal of Engineering, Business and Management (IJEBM), 5.

[14] Abdullah, N. N., \& Anwar, G. (2021). An Empirical Analysis of Natural Gas as an Alternative Fuel for Internal Transportation. International Journal of English Literature and Social Sciences, 6(1).

[15] Tronchin, L., Manfren, M., \& Nastasi, B. (2018). Energy efficiency, demand side management and energy storage technologies-A critical analysis of possible paths of integration in the built environment. Renewable and Sustainable Energy Reviews, 95, 341-353.

[16] Anwar, G., \& Shukur, I. (2015). Job satisfaction and employee turnover intention: A case study of private hospital in Erbil. International Journal of Social Sciences \& Educational Studies, 2(1), 73. 
[17] Moşteanu, N. R., \& Faccia, A. (2020). Digital Systems and New Challenges of Financial Management-FinTech, XBRL, Blockchain and Cryptocurrencies. Quality-Access to Success Journal, 21(174), 159-166.

[18] Anwar, G., \& Abdullah, N. N. (2021). Inspiring future entrepreneurs: The effect of experiential learning on the entrepreneurial intention at higher education. International Journal of English Literature and Social Sciences, 6.

[19] Ali, B. J., \& Anwar, G. (2021). Business strategy: The influence of Strategic Competitiveness on competitive advantage. International Journal of Electrical, Electronics and Computers, 6(2).

[20] He, P., Niu, H., Sun, Z., \& Li, T. (2020). Accounting index of COVID-19 impact on Chinese industries: A case study using big data portrait analysis. Emerging Markets Finance and Trade, 56(10), 2332-2349.

[21] Ali, B. J., \& Anwar, G. (2021). A study of knowledge management alignment with production management: A study of carpet manufacture in Kurdistan region of Iraq. Ali, BJ, \& Anwar, G.(2021). A Study of Knowledge Management Alignment with Production Management: a Study of Carpet Manufacture in Kurdistan Region of Iraq. International Journal of English Literature and Social Sciences, 6(2), 346360.

[22] Putra, Y. M. (2019). Analysis of Factors Affecting the Interests of SMEs Using Accounting Applications. Journal of Economics and Business, 2(3), 818-826.

[23] Ali, B. J., \& Anwar, G. (2021). Strategic leadership effectiveness and its influence on organizational effectiveness. International Journal of Electrical, Electronics and Computers, 6(2).

[24] Coyne, J. G., \& McMickle, P. L. (2017). Can blockchains serve an accounting purpose?. Journal of Emerging Technologies in Accounting, 14(2), 101-111.

[25] Ali, B. J., Saleh, P. F., Akoi, S., Abdulrahman, A. A., Muhamed, A. S., Noori, H. N., \& Anwar, G. (2021, May). Impact of Service Quality on the Customer Satisfaction: Case study at Online Meeting Platforms. In Ali, BJ, Saleh, Akoi, S., Abdulrahman, AA, Muhamed, AS, Noori, HN, Anwar, G.(2021). Impact of Service Quality on the Customer Satisfaction: Case study at Online Meeting Platforms. International journal of Engineering, Business and Management (Vol. 5, No. 2, pp. 65-77).

[26] Bebbington, J., Russell, S., \& Thomson, I. (2017). Accounting and sustainable development: Reflections and propositions. Critical Perspectives on Accounting, 48, 2134.

[27] Ali, B. J., \& Anwar, G. (2021). Organization citizenship behaviour as a determining Factor in Business outcome. Ali, BJ, \& Anwar, G.(2021). Organization citizenship behaviour as a determining Factor in Business outcome. International journal of Rural Development, Environment and Health Research, 5(2), 17-25.

[28] Pratama, F. A., Kaslani, K., Nurdiawan, O., Rahaningsih, N., \& Nurhadiansyah, N. (2020, March). Learning Innovation Using the Zahir Application in Improving Understanding of Accounting Materials. In Journal of Physics: Conference Series (Vol. 1477, No. 3, p. 032018). IOP Publishing.
[29] Ali, BJ, \& Anwar, G.(2021). Marketing Strategy: Pricing strategies and its influence on consumer purchasing decision. International journal of Rural Development, Environment and Health Research, 5(2), 26-39.

[30] Hall, M., \& O'Dwyer, B. (2017). Accounting, nongovernmental organizations and civil society:: The importance of nonprofit organizations to understanding accounting, organizations and society. Accounting, Organizations and Society.

[31] Ali, B. J., \& Anwar, G. (2021). Intellectual capital: A modern model to measure the value creation in a business. Ali, BJ, \& Anwar, G.(2021). Intellectual capital: A modern model to measure the value creation in a business. International journal of Engineering, Business and Management, 5(2), 31-43.

[32] Anwar, G., \& Shukur, I. (2015). the impact of recruitment and selection on job satisfaction: Evidence from private school in Erbil. International Journal of Social Sciences \& Educational Studies, 1(3), 4-13.

[33] Bonsón, E., \& Bednárová, M. (2019). Blockchain and its implications for accounting and auditing. Meditari Accountancy Research.

[34] Anwar, G., \& Abd Zebari, B. (2015). The Relationship between Employee Engagement and Corporate Social Responsibility: A Case Study of Car Dealership in Erbil, Kurdistan. International Journal of Social Sciences \& Educational Studies, 2(2), 45.

[35] Dillard, J., \& Vinnari, E. (2019). Critical dialogical accountability: From accounting-based accountability to accountability-based accounting. Critical Perspectives on Accounting, 62, 16-38.

[36] Anwar, G., \& Shukur, I. (2015). The Impact of Service Quality Dimensions on Students' Satisfaction. International Journal of Social Sciences \& Educational Studies, 76.

[37] Bebbington, J., \& Unerman, J. (2020). Advancing research into accounting and the UN sustainable development goals. Accounting, Auditing \& Accountability Journal.

[38] Lev, B. (2019). Ending the accounting-for-intangibles status quo. European Accounting Review, 28(4), 713-736.

[39] Anwar, G., \& Surarchith, N. K. (2015). Factors Affecting Shoppers' Behavior in Erbil, Kurdistan-Iraq. International Journal of Social Sciences \& Educational Studies, 1(4), 10.

[40] Pincus, K. V., Stout, D. E., Sorensen, J. E., Stocks, K. D., \& Lawson, R. A. (2017). Forces for change in higher education and implications for the accounting academy. Journal of Accounting Education, 40, 1-18.

[41] Ali, B. J., \& Anwar, G. (2021). Measuring competitive intelligence Network and its role on Business Performance. International Journal of English Literature and Social Sciences, 6(2).

[42] Bebbington, J., \& Unerman, J. (2018). Achieving the United Nations Sustainable Development Goals: an enabling role for accounting research. Accounting, Auditing \& Accountability Journal.

[43] Ostaev, G. Y., Khosiev, B. N., Nekrasova, E. V., Frantsisko, O. Y., Markovina, E. V., \& Kubatieva, L. M. (2019). Improving the methodology for assessing the efficiency of labor in organizations of the agroindustrial complex: 
strategic accounting and analysis. Indo American Journal of Pharmaceutical Sciences, 6(5), 9114-9120.

[44] Ali, B. J., \& Anwar, G. (2021). Self-Leadership Skills as Intangible Resources for Sustainable Competitive Advantage. Advanced Engineering Science, 46(1).

[45] Bebbington, J., Österblom, H., Crona, B., Jouffray, J. B., Larrinaga, C., Russell, S., \& Scholtens, B. (2019). Accounting and accountability in the Anthropocene. Accounting, Auditing \& Accountability Journal.

[46] Hein, L., Bagstad, K. J., Obst, C., Edens, B., Schenau, S., Castillo, G., ... \& Caparrós, A. (2020). Progress in natural capital accounting for ecosystems. Science, 367(6477), 514515.

[47] Ali, B. J., \& Anwar, G. (2021). Academic Teaching Skills: Determining the Methods of Teaching to Undergraduate Students. Ali, BJ, \& Anwar, G.(2021). Academic Teaching Skills: Determining the methods of teaching to undergraduate students. International Journal of English Literature and Social Sciences, 6(3), 155-162.

[48] Cockcroft, S., \& Russell, M. (2018). Big data opportunities for accounting and finance practice and research. Australian Accounting Review, 28(3), 323-333.

[49] Syahputri, Y., Pribadi, T., \& Dalimunthe, H. (2020). The Implementation of Liability Accounting on Managerial Performance in PT. Telkom Tbk, Medan Branch. Budapest International Research and Critics Institute (BIRCIJournal): Humanities and Social Sciences, 3(3), 2395-2402.

[50] Ali, BJ, \& Anwar, G.(2021). Employee Turnover Intention and Job Satisfaction. International Journal of Advanced Engineering, Management and Science, 7(6), 22-30.

[51] Andiola, L. M., Masters, E., \& Norman, C. (2020). Integrating technology and data analytic skills into the accounting curriculum: Accounting department leaders' experiences and insights. Journal of Accounting Education, 50, 100655.

[52] Ali, B. J., Anwer, R. N. A. D., \& Anwar, G. (2021). Private Hospitals' Service Quality Dimensions: The impact of Service Quality Dimensions on patients' satisfaction. Int. J. Med. Phar. Drug Re, 7.

[53] Hörisch, J., Schaltegger, S., \& Freeman, R. E. (2020). Integrating stakeholder theory and sustainability accounting: A conceptual synthesis. Journal of Cleaner Production, 275, 124097.

[54] Ali, B. J., \& Anwar, G. (2021). Stock Exchange Investment: A Study of Factors That Influence Stock Exchange Investment. Ali, BJ, \& Anwar, G.(2021). Stock Exchange Investment: A Study of Factors That Influence Stock Exchange Investment. International Journal of Engineering, Business and Management, 5(3), 39-46.

[55] Kaya, C. T., Türkyılmaz, M., \& Birol, B. (2019). Impact of RPA technologies on accounting systems. Muhasebe ve Finansman Dergisi, (82).

[56] Ali, B. J., \& Anwar, G. (2021). Work Engagement: How Does Employee Work Engagement influence Employee Satisfaction?. Ali, BJ, \& Anwar, G.(2021). Work Engagement: How Does Employee Work Engagement influence Employee Satisfaction, 10-21.
[57] He, P., Niu, H., Sun, Z., \& Li, T. (2020). Accounting index of COVID-19 impact on Chinese industries: A case study using big data portrait analysis. Emerging Markets Finance and Trade, 56(10), 2332-2349.

[58] Hamad, K. Q., Qader, K. S., \& Sharif, R. J. M. (2021). Effectiveness And Adequacy Of Disclosure Provisions In Tehran Stock Exchange. PalArch's Journal of Archaeology of Egypt/Egyptology, 18(08), 2379-2388.

[59] Ali, B. J., \& Anwar, G. (2021). Vocabulary Learning Strategies and Foreign Language Acquisition at Private Schools.

[60] Ali, BJ, \& Anwar, G.(2021). Vocabulary Learning Strategies and Foreign Language Acquisition at Private Schools. International Journal of English Literature and Social Sciences, 6(3), 163-173.

[61] Garbowski, M., Drobyazko, S., Matveeva, V., Kyiashko, O., \& Dmytrovska, V. (2019). Financial accounting of Ebusiness enterprises. Academy of Accounting and Financial Studies Journal, 23, 1-5.

[62] Ismeal, B. A., Aziz, H. M., Sorguli, S., Qader, K. S., Sabir, B. Y., Hamza, P. A., ... \& Anwar, G. (2021). The Role of External Auditing in Reducing Creative Accounting Practices.

[63] Ali, B. J., \& Anwar, G. (2021). Project Management and Dynamic Work Environments: The relationship between Leadership in Dynamic Work Environments in Kurdistan.

[64] Ali, BJ, \& Anwar, G.(2021). Project Management and Dynamic Work Environments: The relationship between Leadership in Dynamic Work Environments in Kurdistan. International Journal of Civil, Mechanical and Energy Science, 7(3), 10-18.

[65] Hamza, P. A., Sabir, B. Y., Qader, K. S., Aziz, H. M., Ismeal, B. A., Sorguli, S., ... \& Anwar, G. (2021). Global financial markets: Factors influencing the global financial markets.

[66] Ali, B. J., \& Anwar, G. (2021). Implementation of ELearning System Readiness: The Effect of the Cost Readiness on Implementing E-Learning.

[67] Ali, BJ, \& Anwar, G.(2021). Implementation of e-learning system readiness: The effect of the cost readiness on implementing e-learning. International Journal of Electrical, Electronics and Computers, 6(3), 27-37.

[68] Ali, B. J., \& Anwar, G. (2021). Anxiety and Foreign Language Learning: Analysis of Students' Anxiety Towards Foreign Language Learning.

[69] Ali, BJ, \& Anwar, G.(2021). Anxiety and Foreign Language Learning: Analysis of students' anxiety towards Foreign language learning. International Journal of English Literature and Social Sciences, 6(3), 234-244.

[70] Sorguli, S., Hamza, P. A., Ismeal, B. A., Sabir, B. Y., Aziz, H. M., Qader, K. S., ... \& Gardi, B. (2021). Adaption of EFilling of Income Tax Returns in Kurdistan.

[71] Ali, B. J., \& Anwar, G. (2021). Real Estates Strategies: Analysis of Strategic Management Practices in Real Estate Companies.

[72] Sabir, B. Y., Qader, K. S., Hamza, P. A., Ali, B., Ismeal, S. S., Aziz, H. M., ... \& Anwar, G. (2021). Analysis of Accounting-Based Measures of Expected Returns: A Study of Private SME In Kurdistan. 
[73] Ali, BJ, \& Anwar, G.(2021). Real Estates Strategies: Analysis of Strategic Management Practices in Real Estate Companies. International Journal of Rural Development, Environment and Health Research, 5(3), 35-48.

[74] Qader, K. S., Ismeal, B. A., Aziz, H. M., Hamza, P. A., Sorguli, S., Sabir, B. Y., ... \& Gardi, B. (2021). The Effect of Human Resources Management Skills on Accounting Information Quality in Kurdistan Public Sector. Journal of Humanities and Education Development (JHED), 3(3), 131143.

[75] Ali, B. J., \& Anwar, G. (2021). Administrative Crisis: The Role of Effective Leadership Styles in Crisis Management. Ali, BJ, \& Anwar, G.(2021). Administrative Crisis: The Role of Effective Leadership Styles in Crisis Management. International Journal of Advanced Engineering, Management and Science, 7(6), 31-41.

[76] Aziz, H. M., Sorguli, S., Hamza, P. A., Sabir, B. Y., Qader, K. S., Ismeal, B. A., ... \& Gardi, B. (2021). Factors affecting International Finance Corporation. Journal of Humanities and Education Development (JHED), 3(3), 148-157.

[77] Ali, B. J., \& Anwar, G. (2021). Corporate Social Responsibility: The Influence of Employee Engagement on Corporate Social Responsibility. Journal of Humanities and Education Development (JHED), 3(3), 77-83.

[78] Ali, BJ, Gardi, B., Othman, BJ, Sabir, BY, Sorguli, S., Ismael, NB, Hamza, PA, Aziz, HM, Ahmed, AA, Anwar, G.(2021). The Role of Shopping Malls on Kurdistan Regional Government's Economy. Journal of Humanities and Education Development, 3(3), 39-53.

[79] Ali, B. J., \& Anwar, G. (2021). Porter's Generic Competitive Strategies and its influence on the Competitive Advantage. Ali, BJ, \& Anwar, G.(2021). Porter's Generic Competitive Strategies and its influence on the Competitive Advantage. International Journal of Advanced Engineering, Management and Science, 7(6), 42-51.

[80] Anwar, G., \& Abdullah, N. N. (2021). A Project Management Improvement Program: Enhancing Production With Implementing the Knowledge Management Principles. Advanced Engineering Science, 46(1).

[81] Aziz, H. M., Sorguli, S., Hamza, P. A., Sabir, B. Y., Qader, K. S., Ismeal, B. A., ... \& Gardi, B. (2021). Factors affecting International Finance Corporation. Journal of Humanities and Education Development (JHED), 3(3), 148-157.

[82] Anwar, K. (2017). Analyzing The Conceptual Model Of Service Quality And Its Relationship With Guests'satisfaction: A Study Of Hotels In Erbil. The International Journal of Accounting and Business Society, 25(2), 1-16.

[83] Ali, BJ, Gardi, B., Othman, BJ, Ismael, NB, Sorguli, S., Sabir, BY, Ahmed, SA, Hamza, PA, Aziz, HM, Anwar, G.(2021). Educational system: The policy of Educational system in Kurdistan Region in public Kindergarten. International Journal of English Literature and Social Sciences.

[84] Anwar, K. (2017). The Role of Effective Leadership in Crisis Management: Study of Private Companies in Kurdistan. Qalaai Zanist Scientific Journal, 2(4), 326-338.
[85] Anwar, K., \& Louis, R. (2017). Factors Affecting Students' Anxiety in Language Learning: A Study of Private Universities in Erbil, Kurdistan. International Journal of Social Sciences \& Educational Studies, 4(3), 160.

[86] Anwar, G. (2015, April). Vocabulary Learning Strategies Of English Language Learners In Northern Cyprus. In $B O O K$ of PROCEEDINGS (p. 226).

[87] Gardi, B. (2021). The effects of computerized accounting system on auditing process: a case study from northern Iraq. Available at SSRN 3838327.

[88] Anwar, G., \& Shukur, I. (2015). Students' Attitudes towards Learning English Language in Erbil. International Journal of Social Sciences \& Educational Studies, 1(4), 17.

[89] Hameed, A. A., \& Anwar, K. (2018). Analyzing the Relationship between Intellectual Capital and Organizational Performance: A Study of Selected Private Banks in Kurdistan. International Journal of Social Sciences \& Educational Studies, 4(4), 39.

[90] Abdullah, M. S., Toycan, M., \& Anwar, K. (2017). The cost readiness of implementing e-learning. Custos E Agronegocio On Line, 13(2), 156-175.

[91] Ismael, N. B., Sorguli, S., Aziz, H. M., Sabir, B. Y., Hamza, P. A., Gardi, B., \& Al-Kake, F. R. A. (2021). The Impact of COVID-19 on Small and Medium-Sized Enterprises in Iraq. Annals of the Romanian Society for Cell Biology, 2496-2505.

[92] Anwar, K., \& Balcioglu, H. (2016). The relationship between transformational leadership characteristics and effectiveness: A case study of construction companies in Erbil. International Journal of Science Technology and Management, 5(2), 250-256.

[93] Anwar, K. (2016). Comparison between cost leadership and differentiation strategy in agricultural businesses. Custos E Agronegocio on Line, 12(2), 212-231.

[94] Gardi, B. (2021). Investigating the effects of Financial Accounting Reports on Managerial Decision Making in Small and Medium-sized Enterprises. Available at SSRN 3838226.

[95] Ali, BJ, Gardi, B., Othman, BJ, Ahmed, SA, Ismael, NB, Hamza, PA, Aziz, HM, Sabir, BY, Anwar, G.(2021). Hotel Service Quality: The Impact of Service Quality on Customer Satisfaction in Hospitality. International Journal of Engineering, Business and Management, 5(3), 14-28.

[96] Anwar, K. (2017). Leading Construction Project Teams: The Effectiveness of Transformational Leadership in Dynamic Work Environments in Kurdistan. International Journal of Advanced Engineering, Management and Science, 3(10), 239925.

[97] Ismael, NB, Othman, BJ, Gardi, B., Hamza, PA, Sorguli, S., Aziz, HM, Ahmed, SA, Sabir, BY, Ali, BJ, Anwar, G.(2021). The Role of Training and Development on Organizational effectiveness. International Journal of Engineering, Business and Management, 5(3), 15-24.

[98] Anwar, K., \& Ghafoor, C. (2017). Knowledge management and organizational performance: A study of private universities in Kurdistan. International Journal of Social Sciences \& Educational Studies, 4(2), 53. 
[99] Anwar, K., \& Qadir, G. H. (2017). A Study of the Relationship between Work Engagement and Job Satisfaction in Private Companies in Kurdistan. International Journal of Advanced Engineering, Management and Science, 3(12), 239944.

[100] Anwar, K. (2017). Factors affecting stock exchange investment in kurdistan. The International Journal of Accounting and Business Society, 25(1), 32-37.

[101] Ahmed, SA, Othman, BJ, Gardi, B., Sabir, BY, Ismael, NB, Hamza, PA, Sorguli, S., Aziz, HM, Ali, BJ, Anwar, G.(2021). Students' Attitudes towards Learning English in the Kurdistan region of Iraq. International Journal of English Literature and Social Sciences, 6(3), 072-087.

[102] Anwar, K., \& Climis, R. (2017). Analyzing the relationship between types of advertisement and customer choice: a study of retailer stores in erbil. The International Journal of Accounting and Business Society, 25(2), 43-52.

[103] Sorguli, S., B. Gardi, B. J. Othman, H. M. Aziz, S. A. Ahmed, B. Y. Sabir, N. B. Ismael, P. A. Hamza, B. J. Ali, and G. Anwar.(2021). "Innovation: Knowledge Management in the Innovating Industries, 6 (3), 10-23."

[104] Anwar, K., \& Louis, R. (2017). Factors Affecting Students' Anxiety in Language Learning: A Study of Private Universities in Erbil, Kurdistan. International Journal of Social Sciences \& Educational Studies, 4(3), 160.

[105] Ali, B. J., \& Anwar, G. (2021). The mediation role of change management in employee development. Ali, BJ, \& Anwar, G.(2021). The Mediation Role of Change Management in Employee Development. International Journal of English Literature and Social Sciences, 6(2), 361-374.

[106] Aziz, HM, Othman, BJ, Gardi, B., Ahmed, SA, Sabir, BY, Ismael, NB, Hamza, PA, Sorguli, S., Ali, BJ, Anwar, G.(2021). Employee Commitment: The Relationship between Employee Commitment And Job Satisfaction. Journal of Humanities and Education Development, 3(3), 54-66.

[107] Ali, B. J., \& Anwar, G. (2021). Measuring competitive intelligence Network and its role on Business Performance. International Journal of English Literature and Social Sciences, 6(2).

[108] Sabir, B. Y., Jabbar Othman, B., Gardi, B., Burhan Ismael, N., Abdalla Hamza, P., Sorguli, S., ... \& Anwar, G. (2021). Administrative Decentralization: The Transfer of Competency from The Ministry of Education to General Directorates. International Journal of Rural Development, Environment and Health Research (IJREH), 5.

[109] Ali, BJ, Anwar, G., Gardi, B., Othman, BJ, Aziz, HM, Ahmed, SA, Hamza, PA, Ismael, NB, Sorguli, S., Sabir, BY (2021). Business Communication Strategies: Analysis of Internal Communication Processes. Journal of Humanities and Education Development, 3(3), 16-38.

[110] Anwar, G. (2015, April). Vocabulary Learning Strategies Of English Language Learners In Northern Cyprus. In BOOK of PROCEEDINGS (p. 226).

[111] Hamza, P. A., Othman, B. J., Gardi, B., Sorguli, S., Aziz, H. M., Ahmed, S. A., ... \& Anwar, G. (2021). Recruitment and Selection: The Relationship between Recruitment and Selection with Organizational Performance. International
Journal of Engineering, Business and Management, 5(3), 113.

[112] Anwar, G., \& Shukur, I. (2015). Students' Attitudes towards Learning English Language in Erbil. International Journal of Social Sciences \& Educational Studies, 1(4), 17. 